\title{
2006 ECOSOC 실질회의(9) - 인도지원분야
}

\section{1. 핵심 요지}

가. 7.18 (화) 표제회의 속개되어 위기상황에서의 유엔의 인도적 조정기능의 강화를 주요 내용 으로 하는 별첨 결의 $(\mathrm{E} / 2006 / \mathrm{L} .13)$ 를 컨센서 스로 채택하고 인도지원분야 논의를 종결하 였음.

- 동 결의는 인도적 지원회의 개막에 앞서 일 본과 자메이카의 조정하에 문안협상을 완료 하였으며 실질회의에서는 별도의 토의없이 컨센서스로 채택됨.

나. 상기 결의 채택에 앞서 만성적 재원부족에 처 한 인도적 위기상황' (Chronically Underfunded Emergencies)이라는 주제로 제2차 공식 패널토의가 개최되었음.

- 동 패널에 참가한 UN 기구 및 각국 대표는 자연재해를 비롯한 각종 긴급상황에서의 인 도적 지원 관련 $\mathrm{UN}$ 및 $\mathrm{UN}$ 기구들의 만성적
재정부족 상황과 재원조달 방안에 대해 논의 하고 만성화된 긴급사태에 대한 공여국들의 지속적인 관심과 지원을 촉구함.

\section{2. 관찰 및 평가}

가. 금번 회의에서는 아프리카 등지의 내전과 기 근 및 최근 빈번해지고 있는 자연재해 등으로 인한 인도적 위기사태를 점검하고 UN 및 UN 기구들의 만성적 재원부족의 문제점을 집중 논의함.

- 이에 따라 인도적 위기사태시 OCHA 합동 어필에 대한 적시대응 등의 방법을 통해 우 리정부 지원의 국제적 visibility를 확보하고 $\mathrm{UN}$ 차원의 지원노력에 동참하기 위해서는 향후 이를 위한 안정적인 재원을 확보하는 방안에 대한 검토가 필요한 것으로 판단됨.

나. 아울러 금번 인도적 지원분야 회의에서 나타 
난 바와 같이 인도적 위기사태에 대한 긴급지 원과 장기적인 개발문제간의 연계 및 조화문 제등이 향후 UN 등 여타 인도지원분야 포럼 에서 비중있게 다루어질 것으로 예상되는 바, 이를 감안, 관련 회의준비 및 참석에 있어 관 련국(局)간 업무협조가 더욱 긴밀히 이루어져 야할 것으로 봄.

\section{3. 제2차 공식패널토의 세부 내용}

가. A. Cavaco EC 인도지원국장은 $\mathrm{EC}$ 는 2005년 인도지원 분야에 총 22 억유로를 기여하는 등 동 분야에서 가장 큰 재정적 기여를 하고 있다고 소개하고, 체첸 - 네팔 - 미얀마 등 인도적 위기 가 장기화된 '잊혀진 재난' (forgotten crises)에 대한 여타 공여국들의 기여를 촉구함.

나. A. Raghe 아프리카구호위원회 의장은 15 년 이 상의 내전과 폭력사태 및 기근으로 인한 소말 리아의 절박한 상황에도 불구하고 국제사회로 부터의 지원은 만성적인 부족상황임을 설명함.

- 특히 동 의장은 현재 소말리아에 대한 UN 합동어필의 평균 $50 \%$ 미만만이 재원조달에 성공하고 있으며 사실상 소말리아의 가장 큰 resource는 국제사회의 원조가 아닌 해외 거주 소말리아인의 본국 송금액이라는 점을 상기함.

다. D. McNamara 긴급구호조정관 특별고문은 콩고 $(\mathrm{DRC}) \cdot$ 수단 · 우간다 등지에서 발생중인
내전과 기근으로 인한 지속적인 국경내 인구 이동이 가져오는 문제점을 지적하며 평화구축 과 개발이라는 장기적인 과제를 위해 공여국 들이 이 문제에 지원을 확대할 것을 촉구함.

- 동 고문은 일례로 2004년 코트디부아르에 대한 ODA가 10 억불에 달했으나 2005년은 2 억불로 감소하였고 이중 절반인 1 억불은 외채상환에 사용되었음을 상기하며 만성적 인 위기를 겪는 국가에 대한 대외원조의 감 소에 우려를 표명함.

라. $\mathrm{EU}$ 대표는 위기상황에서의 인도적 지원은 중 립적이며 공평하게 이루어져야 하며 이에 따 라 EU는 긴급상황에서의 인도적 지원시 earmark를 최대한 자제하고 있다고 설명함.

- 아울러 $\mathrm{CERF}$ 는 인도적 위기시의 만성적 재 원부족 문제 해결에 도움이 될 것이나 이는 어디까지나 기존의 재원조달 메커니즘을 보 완하는 것이지 대체하는 것이어서는 안된다 고 다시 한번 강조함.

마. 아울러 인도적 위기상황을 포함한 만성적인 대개도국 지원부족 문제는 (선진공여국의) 정 치적 의지뿐 아니라 도덕의 문제로 볼 수 있다 는 기니비사우 대표의 지적에 대해 미국대표 는 많은 아프리카 국가의 치안문제가 지원문 제를 더욱 어렵게 하고 있다고 설명함.

[자료: 주제네바대표부] 